\title{
Role of Tax Towards Government Revenue of Nepal
}

\author{
Pravesh Ghimire \\ Nepal Commerce Campus, Faculty of Management, Tribhuvan University, Kathmandu, Nepal
}

Email address:

pravesh_ghimire@hotmail.com

\section{To cite this article:}

Pravesh Ghimire. Role of Tax Towards Government Revenue of Nepal. International Journal of Business and Economics Research. Vol. 8, No. 3, 2019, pp. 85-96. doi: 10.11648/j.ijber.20190803.12

Received: March 25, 2019; Accepted: May 6, 2019; Published: May 29, 2019

\begin{abstract}
A modern government collects required funds through different sources; mainly from revenue and debt. Among different sources, taxation is the most important sources of government revenue and Gross Domestic Product (GDP) of a nation. In this paper, an attempt has been made to examine the contribution of tax revenue to GDP and government revenue of Nepal. The main questions addressed for the study were to find the proportion of tax in government revenue collection and to know whether the resource gap of Nepal is in increasing or decreasing trend. This study is mainly based on secondary data collected from government sources. Nationwide data of both direct and indirect taxes, total government revenue and GDP for the period of last fifteen years from F/Y 2002/03 to F/Y 2016/17 have been taken for the study. In order to assess the contribution of tax revenue on government revenue and GDP, co-relation and multiple regression analysis have been done separately and the results have been verified by using test statistics ( $t$-test and $\mathrm{f}$-tests). Similarly, to observe the long-term growth of tax revenue, time series analysis has been done by using straight line trend method. The study has concluded that GDP and government revenue have been strongly related with direct and indirect tax revenues of Nepal.
\end{abstract}

Keywords: Contribution of Tax Revenue (TR), Gross Domestic Product (GDP), Government Revenue (GR), Direct Tax (DT), Indirect Tax (IDT), Co-relation, Multiple Regression, Time Series Analysis

\section{Introduction}

A tax is a mandatory financial charge or some other type of levy imposed upon a taxpayer whether an individual or other legal entity by a governmental organization in order to fund various public expenditures. The government requires a huge amount of resources for carrying out various development and welfare activities in the country which it collects by imposing taxes. In other words, raising government revenue to meet the ever increasing government expenditure has become an important objective of taxation. The government not only, raises public revenue through taxation but also, imposes restrictions on the use of certain goods and services. The government regulates an economy in accordance with the needs of the country. Tax helps in redistributing wealth in the country. Tax is imposed on individuals according to their income level. High earners are imposed high tax through progressive tax system. It prevents wealth from being concentrated in a few hands of the rich and hence narrows down the gap between the rich and the poor. Tax collected by the government is spent for infrastructural development and public welfare. In this way, the wealth of the high earners is redistributed to the whole community. Tax serves as an instrument for promoting economic growth, stability and efficiency. The government controls or expands the economic activities of the country by providing various concessions, rebates and other facilities. Low rate of taxation during a business depression will accelerate more income to the people and help in raising demand and thus revive business activity. On the contrary, high rates may be useful to check inflationary pressure on prices. Tax policy may be used as a regulatory mechanics to achieve price stability, check business booms and depression. The government can reduce the unemployment problem in the country by promoting various employment generating activities. Industries established in remote parts or industries providing more employment are given more facilities. As a result, the unemployment problem can be reduced to a great extent through liberal tax policy. Regional disparity has become a chronic problem to the developing countries like Nepal. Tax is one of the ways through which regional disparities can be minimized. The government provides tax exemptions or concessions for industries established or activities carried out 
in backward areas. This will help increase economic activities in those areas and ultimately regional disparity reduces to minimum.

Tax can be classified into two categories direct tax and indirect tax. A direct tax is a tax paid by a person or whom it is legally imposed. In direct tax, the person paying and bearing tax cannot collect direct tax from other person. It is collected directly by the government from the person who bears the tax burden. Taxpayers need to file tax returns directly to the government. Therefore, direct tax cannot be shifted. The impact or the money burden and the incidence are on the one and the same person. In other words, the same person pays and bears the tax burden. It is the tax on income and property. Examples include income tax, property tax, vehicle tax, interest tax, expenditure tax, death tax, gift tax, etc. Direct tax is equitable as it is imposed on person as per the size of property or income. Time, procedure and amount of tax to be paid is known with certainty. The cost of collecting direct taxes is low as they are mostly collected at the source. If the government suddenly needs more funds in an emergency, direct taxes can well serve the purpose. The yield from income tax can be easily increased by raising tax rate. As a community grows in numbers and prosperity, the return from direct taxes expands automatically. The direct taxes yield large revenue to the government.

On the other hand, an indirect tax is a tax imposed on one person but partly or wholly paid by another. In indirect tax, the person paying and bearing the tax is different. It is collected by mediators who transfer the taxes to the government and also perform functions associated with filing tax returns. Hence, indirect tax can be shifted. It is the tax on consumption or expenditures. Examples include VAT, excise duty, import \& export duty. It is more convenient as the taxpayer does not have to pay a lump sum amount for tax. It is paid in small amounts and only when making purchases. There is mass participation as each and every person getting goods or services has to pay tax. Indirect tax is also the means of reaching the lower income individuals as they are generally exempted from paying direct taxes. There is less chance of tax evasion as the taxpayers pay the tax collected from customers. The collection of tax takes automatically when goods are bought and sold. The government can check on the consumption of harmful goods by imposing higher taxes.

The main objective of this study is to examine the contribution of tax to government revenue of Nepal. The main questions addressed for the study are to find the proportion of tax in government revenue collection and to know whether the resource gap of Nepal is in increasing or decreasing trend.

\section{Review of Literature}

Feldstein (1995) published an article entitled "The Effects of Tax-Based Saving Incentives on Government Revenue and National Saving". This paper shows that previous analyses of Individual Retirement Account (IRA)-type plans that seek to encourage household saving, have miscalculated their effect on tax revenue and therefore, on national saving by ignoring their favorable impact on corporate tax payments. Recognizing the important effects of IRA plans on corporate tax revenue charges, previous conclusions about the revenue loss is a fundamental way. The revenue loss associated with IRAs either is much smaller than that has generally been estimated or is actually a revenue gain [1].

Nepal Rastra Bank (2002) published a journal entitled, "Trend in Nepal's import duties: implications with future trade liberalization". The journal states that Nepal has been accelerating the process of trade liberalization from the mideighties which has been reflected by membership of WTO, agreement of a framework for a Free Trade Area (FTA) in south Asia and entering an FTA [2].

Gupta (2007) published an article entitled "Determinants of Tax Revenue Efforts in Developing Countries". This paper contributes to the existing literature on the principal determinants of tax revenue performance across developing countries by using a broad dataset and accounting for some econometric issues that were previously ignored. The results confirm that structural factors like: per capita GDP, agriculture share in GDP, trade openness and foreign aid significantly affect revenue performance of an economy. Other structural factors include corruption, political stability, share of direct and indirect taxes etc. The paper also makes use of a revenue performance index, and finds that while several Sub Saharan countries are performing well above their potential, some Latin American economies fall short of their revenue potential [3].

K. C. (2006) had published a book in entitled "Tax laws and tax planning: theory and practice". He described the conceptual foundation, basic concepts of income taxation of Nepal, VAT act in Nepal and tax planning. This book had presented practical as well as theoretical aspects. The book was useful to the students, tax administrator, auditors and research work [4].

Taha et al. (2008) published an article entitled "Causality between Tax Revenue and Government spending in Malaysia". The journal shows the trend of tax collection in Malaysia is inconsistent, with economic conditions. Total tax revenue has always been a major contribution to Malaysia's federal government revenue. Income tax is one of the surest ways to fund the government. The study empirically tests the causality between tax revenues and government spending in Malaysia for the past 36 years by applying an econometric models. The results provide evidence for the existence of a long-run relationship between tax revenues and government spending with unidirectional and bidirectional causality in VAR models for the sample period 1970-2006 [5].

Agrawal (2009) published a book named "Income Tax: theory and practice." This book was also source of information of the subject of income tax. Sufficient theoretical concepts with clear interpretation as well as sufficient examples were included in this book [6].

Prasad (2015) published an article entitled "Nepal's excise systems and the legal frameworks: agendas for reform". The principal objective of this article was to analyze the existing 
system of excise administration in Nepal and identify ways in which the administrative burden might be reduced for both taxpayers and the government [7].

Yadav et al. (2015) published an article entitled, "Contribution of income tax and effects on revenue generation of Nepal". The study focusses on the structure and trend of income tax and its contribution to government revenue, composition of direct tax, ways of generating more income tax, prospect of online taxpaying system, tax evasion and ways of controlling, trend of resource gap and contribution of income tax revenue to GDP [8].

Rossignolo (2016) published a paper named "Taxes, Expenditures, Poverty and Income Distribution in Argentina". This paper estimates the impact of tax and expenditure policies on income distribution and poverty in Argentina through data collected from the national household survey on incomes and expenditures in the year 2012-2013, by standard fiscal incidence analysis. Fiscal policy has been a powerful tool in reducing inequality and poverty as on outcome of the study. In spite of this, the high levels of public spending may make the programs of fiscal policy unsustainable in long run. [9]

Morrisey et al. (2016) published a paper entitled, "Tax Revenue Performance and Vulnerability in Developing Countries". This paper addresses vulnerability of revenue to external shocks using export composition in order to capture economic structure. It further differentiates countries according to income levels, resource endowments and political regimes. It was found that lower income countries were vulnerable to external shocks, especially in terms of trade associated with the greatest revenue loss. Moreover, democratic regimes seem to be less vulnerable to revenue losses due to external shocks than non-democracies regimes. Whereas, revenue in resource rich countries is more vulnerable to external shocks except natural disasters in comparison to countries with limited resources. A negative relationship between manufacturing exports and revenue was obtained in lower income countries. [10]

Ajayi et al. (2016) published a paper entitled, "An evaluation of the relationship between variations in provision of infrastructural and payment of property tax in Ibadan north-east local government, Nigeria". This study emphasizes provision of infrastructural facilities by any government through the use of property tax to finance the provisions of infrastructure as a global practice. However, without proper form of property taxation which can be applied, residents cannot determine the benefit derivable from the infrastructural provided. The research methodology therefore adopted system random sampling in Ibadan North East Local Government to examine the $0.0035 \%$ of the resident population taking the occupants of the residential property within location formed the sample frame. The result indicated that more than a half of the population reside in areas with low infrastructure. Further it showed, the current form of property taxation has created social injustice since the amount of tax collected is somehow similar irrespective of the level of infrastructural provided. Improvement of land legislation was therefore recommended as the basis for determining property tax. [11]

Mascagni (2016) published a paper entitled, "A Fiscal History of Ethiopia: Taxation and Aid Dependence 19602010". This paper reviews the fiscal history of Ethiopia, focusing particularly on the period between 1960 and 2010, for which detailed fiscal data is available to underpin the analysis. During the course of reviewing the key fiscal and economic events of this period, particular attention is paid to the relation between Ethiopia and its donors. This at fiscal terms can be seen as a relation between mobilization of own tax revenue and negotiation of aid with the conditions attached to it. Furthermore, observing at the main drivers and constraints to tax revenue mobilization at this period, the paper explores the role played by the donors and the influence of historical background of Ethiopia on present date. [12]

Dhakal et al. (2017) published a book named "Tax laws and tax planning". The books as shown taxable income in computed under employment, business and investment sources. Further, many aspects of exemptions, deductions, provision for depreciation, income from major heads, tax planning, tax evasion, VAT, customs and excise were introduced with proper examples and concepts [13].

Ghodsi et al. (2018) published a paper entitled, "UK Taxes and Tax Revenues: Composition and Trends". This study looks at the composition and trends of tax revenues in the UK and provides a brief overview of somehow complicated system of three main taxes: personal income tax, national insurance contributions (NICs) and value added tax (VAT) in the UK. These taxes are shown to account for about three quarters of all tax revenues which has been stable over a period of time. In comparison to other countries, UK is similar in its tax dominate revenues. The study examines monthly tax revenues for these three taxes, using econometrically estimated trends. It finds that, in constant price terms, revenues have grown slowly and steadily over time, broadly keeping pace with growth in real GDP. Moreover, tax revenue forecasting is mainly undertaken by an independent body which publishes forecasts at the level of receipts for individual taxes. This considerably reduces the risk of political biasness in these revenue forecast. [14]

Mahler (2018) published a paper entitled, "Indirect taxes and government inequality reduction: A cross-national analysis of the developed world". This article explores the role of indirect taxes in helping to finance public social transfers in the developed countries, with special attention to the countries whose social benefit programs provide the most inequality reduction and tend to finance those programs with the most regressive tax mix. It finds that the share of indirect taxes in a country's GDP and the degree to which market inequality is reduced by public social transfers are positively related. While controlling for other tax types, the share of the population that is elderly and unemployed with a large indirect tax burden is politically possible. This is because of some combinations of fiscal illusion and the fact that indirect taxes do not retard economic growth or investment. The high indirect taxes that finance public social transfers are often the 
product of a political process in which democratic corporatism, institutional and union density play key roles. The article concludes with a discussion of the incidence of indirect taxes, finding that their regressive effect is outweighed by the redistribution accomplished by the public social transfers which help to finance. [15]

\section{Research Methodology}

\subsection{Variable Specification}

Tax revenue consisting of direct and indirect taxes has been taken as independent variable while, government revenue or total revenue and GDP have been taken as dependent variables in this study. This study solely depends on secondary data collected from government publications through Economic Surveys and through visiting websites. Information and data have been processed and tabulated by using Microsoft Excel and then transformed to Microsoft Word. To analyze and draw the required conclusion from the collected data and descriptive and inferential statistical tool have been used by using SPSS.

\subsection{Model Specification}

\subsubsection{Co-relation}

Co-relation coefficient between GDP and tax revenue along with government revenue and tax revenue have been calculated to show the degree and direction of co-relation between these variables.

\subsubsection{Multiple Regression}

The relation between government revenue to direct tax and indirect tax have been calculated through the model or Regression Equations of $\mathrm{Y}$ on $\mathrm{X}_{1}$ and $\mathrm{X}_{2}$.

$$
\mathrm{Y}=\mathrm{a}+\mathrm{b}_{1} \mathrm{X}_{1}+\mathrm{b}_{2} \mathrm{X}_{2}
$$

Where, $\mathrm{Y}=$ Government revenue, $\mathrm{X}_{1}=$ Direct tax, $\mathrm{X}_{2}=$ Indirect tax

\subsubsection{Time-series}

Time-series analysis of tax revenue along with time has been done by using the Equation of straight line trend as:

$$
\mathrm{Y}=\mathrm{a}+\mathrm{bX}
$$

Where, $\mathrm{Y}=$ Tax revenue, $\mathrm{X}=$ Time

\subsubsection{Hypothesis Testing}

T-test has been used to test the overall significance of the estimated multiple regression equations. Similarly, F-test has been done for measuring overall significance of the model [16].

\section{Presentation and Analysis of Data}

This chapter is concerned with the presentation and analysis of data obtained through different secondary sources. It is the focal part of the study to analyze direct and indirect tax contribution to government revenue.

\subsection{Structure of Government Revenue of Nepal}

The sources of government revenue are divided into tax revenue and non- tax revenue. The table shows the trend of government revenue and its components in past fifteen financial years. We can observe that tax revenue holds major portion of government revenue in comparison to non- tax revenue.

\begin{tabular}{|c|c|c|c|c|c|}
\hline $\mathbf{F} / \mathbf{Y}$ & Tax revenue & Non- tax revenue & $\begin{array}{l}\text { Government } \\
\text { revenue }\end{array}$ & $\begin{array}{l}\text { Percentage of tax revenue } \\
\text { to government revenue }\end{array}$ & $\begin{array}{l}\text { Percentage of non- tax revenue } \\
\text { to government revenue }\end{array}$ \\
\hline $2002 / 03$ & $40,896.00$ & $13,642.90$ & $54,538.90$ & 74.99 & 25.01 \\
\hline $2003 / 04$ & $48,173.00$ & $14,158.00$ & $62,331.00$ & 77.29 & 22.71 \\
\hline $2004 / 05$ & $54,104.70$ & $16,018.00$ & $70,122.70$ & 77.16 & 22.84 \\
\hline $2005 / 06$ & $57,430.40$ & $14,851.50$ & $72,281.90$ & 79.45 & 20.55 \\
\hline $2006 / 07$ & $71,126.70$ & $16,585.40$ & $87,712.10$ & 81.09 & 18.91 \\
\hline $2007 / 08$ & $85,155.50$ & $22,467.00$ & $107,622.50$ & 79.12 & 20.88 \\
\hline $2008 / 09$ & $117,051.90$ & $26,422.60$ & $143,474.50$ & 81.58 & 18.42 \\
\hline $2009 / 10$ & $159,785.30$ & $18,206.40$ & $177,991.70$ & 89.77 & 10.23 \\
\hline $2010 / 11$ & $177,227.20$ & $21,148.70$ & $198,375.90$ & 89.34 & 10.66 \\
\hline $2011 / 12$ & $211,722.60$ & $32,651.40$ & $244,374.00$ & 86.64 & 13.36 \\
\hline $2012 / 13$ & $259,214.90$ & $36,806.20$ & $296,021.10$ & 87.57 & 12.43 \\
\hline $2013 / 14$ & $312,441.20$ & $44,179.50$ & $356,620.70$ & 87.61 & 12.39 \\
\hline $2014 / 15$ & $355,955.70$ & $49,910.70$ & $405,866.40$ & 87.7 & 12.3 \\
\hline $2015 / 16$ & $421,096.60$ & $60,865.00$ & $481,961.60$ & 87.37 & 12.63 \\
\hline $2016 / 17$ & $553,867.00$ & $55,313.00$ & $609,180.00$ & 90.92 & 9.08 \\
\hline Total & $2,925,248.70$ & $443,226.30$ & $3,368,475.00$ & & \\
\hline Average & $365,656.09$ & $55,403.29$ & $421,059.38$ & 83.84 & 16.16 \\
\hline
\end{tabular}

Table 1. Composition of tax and non-tax revenue in Nepal (Rs. in million).

Source: Economic Survey, Ministry of Finance, Nepal, F/Y 2011/12 to 2017/18

We can observe that tax revenue holds major portion of government revenue in comparison to non- tax revenue. At the F/Y 2002/03, the tax revenue composed of 40,896 million which is around 75 percent of government revenue whereas, non-tax revenue composed 13,643 million which is of around 25 percent of government revenue. But along with time, the 
composition of tax revenue has been showing increasing trend while, the composition of non- tax revenue has been showing increasing as well as decreasing trend. At $\mathrm{F} / \mathrm{Y}$ 2016/2017, the tax revenue composed of around 91 percent of government revenue whereas, non- tax revenue composed of around 9 percent of government revenue. On an average, tax revenue comprises 83.84 percent while, non-tax revenue comprises 16.16 percent of government revenue. Thus, tax revenue is significant source of government revenue.

\subsection{Share of Government Revenue and Tax Revenue to GDP}

Government Revenue is sum total of tax revenue and nontax revenue the data of which is mentioned below. The government revenue and tax revenue is compared with GDP. The table shows the trend of tax and government revenue compared with GDP over past fifteen years.

Table 2. Government revenue and tax revenue as a percentage of GDP (Rs. in million).

\begin{tabular}{|c|c|c|c|c|c|}
\hline $\mathbf{F} / \mathbf{Y}$ & Tax revenue & Government revenue & GDP at basic price & $\begin{array}{l}\text { Share of government } \\
\text { revenue to GDP }\end{array}$ & $\begin{array}{l}\text { Share of tax } \\
\text { revenue to GDP }\end{array}$ \\
\hline $2002 / 03$ & $40,896.00$ & $54,538.90$ & $767,582.00$ & 7.11 & 5.33 \\
\hline $2003 / 04$ & $48,173.00$ & $62,331.00$ & $837,682.00$ & 7.44 & 5.75 \\
\hline $2004 / 05$ & $54,104.70$ & $70,122.70$ & $914,088.00$ & 7.67 & 5.92 \\
\hline $2005 / 06$ & $57,430.40$ & $72,281.90$ & $1,013,977.00$ & 7.13 & 5.66 \\
\hline $2006 / 07$ & $71,126.70$ & $87,712.10$ & $1,126,300.00$ & 7.79 & 6.32 \\
\hline $2007 / 08$ & $85,155.50$ & $107,622.50$ & $1,264,601.00$ & 8.51 & 6.73 \\
\hline $2009 / 10$ & $159,785.30$ & $177,991.70$ & $1,772,694.00$ & 10.04 & 9.01 \\
\hline $2010 / 11$ & $177,227.20$ & $198,375.90$ & $2,052,228.00$ & 9.67 & 8.64 \\
\hline $2011 / 12$ & $211,722.60$ & $244,374.00$ & $2,298,248.00$ & 10.63 & 9.21 \\
\hline $2012 / 13$ & $259,214.90$ & $296,021.10$ & $2,525,886.00$ & 11.72 & 10.26 \\
\hline $2013 / 14$ & $312,441.20$ & $356,620.70$ & $2,876,673.00$ & 12.4 & 10.86 \\
\hline $2014 / 15$ & $355,955.70$ & $405,866.40$ & $3,099,248.00$ & 13.1 & 11.49 \\
\hline $2015 / 16$ & $421,096.60$ & $481,961.60$ & $3,243,996.00$ & 14.86 & 12.98 \\
\hline Average & $195,016.58$ & $224,565.00$ & $1,937,416.20$ & 10.25 & 8.71 \\
\hline
\end{tabular}

Source: Economic Survey, Ministry of Finance, Nepal, F/Y 2011/12 to 2017/18

GDP was 767,582 million in F/Y 2002/03 and has been increasing with time and reached $3,759,190$ million in $F / Y$ 2016/17 which increased by around 4.8 times over fifteen years. Percentage of tax revenue to GDP has shown increasing as well as decreasing trend over time. But, overall percentage of tax revenue to GDP is in increasing trend though it has decreased in some F/Y. This is because tax revenue has increased at greater proportion than increase in GDP. On an average, tax revenue comprises 8.71 percent of GDP. Percentage of government revenue to GDP has shown increasing as well as decreasing trend over time. It has shown an overall increasing trend. On an average, government revenue comprises of 10.25 percent of GDP.

\subsection{Contribution of Direct Tax to GDP, Government Revenue and Tax Revenue}

Ratio of direct tax to GDP, government revenue and tax revenue are calculated. The data of GDP, government revenue (GR) and tax revenue (TR) are taken from Table 1 and Table 2.

Table 3. Contribution of direct tax to GDP, government revenue and tax revenue (Rs. in million).

\begin{tabular}{|c|c|c|c|c|}
\hline $\mathbf{F} / \mathbf{Y}$ & Direct tax (DT) & \% of DT to GDP & \% of DT to GR & \% of DT to TR \\
\hline $2002 / 03$ & $10,881.90$ & 1.42 & 19.95 & 26.61 \\
\hline $2003 / 04$ & $11,912.60$ & 1.42 & 19.11 & 24.73 \\
\hline $2004 / 05$ & $13,071.80$ & 1.43 & 18.64 & 24.16 \\
\hline $2005 / 06$ & $13,968.10$ & 1.38 & 19.32 & 24.32 \\
\hline $2006 / 07$ & $18,980.30$ & 1.69 & 21.64 & 26.69 \\
\hline $2007 / 08$ & $23,087.70$ & 1.83 & 21.45 & 27.11 \\
\hline $2008 / 09$ & $34,319.70$ & 2.27 & 23.92 & 29.32 \\
\hline $2010 / 11$ & $46,720.30$ & 2.28 & 23.55 & 26.36 \\
\hline $2011 / 12$ & $57,770.20$ & 2.51 & 23.64 & 27.29 \\
\hline $2012 / 13$ & $73,012.60$ & 2.89 & 24.66 & 28.17 \\
\hline $2013 / 14$ & $86,742.30$ & 3.02 & 24.32 & 27.76 \\
\hline $2014 / 15$ & $101,089.20$ & 3.26 & 24.91 & 28.4 \\
\hline $2015 / 16$ & $133,268.80$ & 4.11 & 27.65 & 31.65 \\
\hline $2016 / 17$ & $172,238.70$ & 4.58 & 28.27 & 31.1 \\
\hline Average & $55,830.68$ & 2.42 & 22.92 & 27.26 \\
\hline
\end{tabular}

Source: Economic Survey, Ministry of Finance, Nepal, F/Y 2011/12 to 2017/18 
Ratio of direct tax to GDP has shown overall increasing trend, from F/Y 2002/03 at 1.42 percent up to F/Y 2016/2017 at 4.58 percent with a decreasing trend in F/Y 2005/06 only. On an average, direct tax comprises of 2.42 percent of GDP. Ratio of direct tax to government revenue has shown overall increasing trend from $\mathrm{F} / \mathrm{Y} 2002 / 03$ at 19.95 percent up to $\mathrm{F} / \mathrm{Y}$ $2016 / 2017$ at 28.27 percent with a decreasing trend in $\mathrm{F} / \mathrm{Y}$ 2005/06 and 2006/07. On an average, direct tax comprises of 22.92 percent of government revenue. Ratio of direct tax to tax revenue has shown overall increasing trend from $\mathrm{F} / \mathrm{Y}$ 2002/03 at 26.61 percent up to F/Y 2016/17 at 31.1 percent with a decreasing trend in F/Y 2004/05, 2009/10, 2013/14. On an average, direct tax comprises of 27.26 percent of tax revenue.

\subsection{Contribution of Indirect Tax to GDP, Government Revenue and Tax Revenue}

Ratio of indirect tax to GDP, government revenue and tax revenue is calculated. The data of GDP, government revenue (GR) and tax revenue are taken from Table 1. and Table 2.

Table 4. Contribution of indirect tax to GDP, government revenue and tax revenue (Rs. in million).

\begin{tabular}{|c|c|c|c|c|}
\hline $\mathbf{F} / \mathbf{Y}$ & Indirect tax (IDT) & $\%$ of IDT to GDP & $\%$ of IDT to GR & $\%$ of IDT to TR \\
\hline $2002 / 03$ & $30,014.10$ & 3.91 & 55.03 & 73.39 \\
\hline $2003 / 04$ & $36,260.40$ & 4.33 & 58.17 & 75.27 \\
\hline $2004 / 05$ & $41,032.90$ & 4.49 & 58.52 & 75.84 \\
\hline $2006 / 07$ & $52,146.40$ & 4.63 & 59.45 & 73.31 \\
\hline $2007 / 08$ & $62,067.80$ & 4.91 & 57.67 & 72.89 \\
\hline $2008 / 09$ & $82,731.20$ & 5.48 & 57.66 & 70.68 \\
\hline $2010 / 11$ & $130,506.90$ & 6.36 & 65.79 & 73.64 \\
\hline $2011 / 12$ & $153,951.60$ & 6.7 & 63 & 72.71 \\
\hline $2012 / 13$ & $186,202.30$ & 7.37 & 62.9 & 71.83 \\
\hline $2013 / 14$ & $225,698.90$ & 7.85 & 63.29 & 72.24 \\
\hline $2014 / 15$ & $254,866.50$ & 8.22 & 62.8 & 71.6 \\
\hline $2015 / 16$ & $287,827.80$ & 8.87 & 59.72 & 68.35 \\
\hline $2016 / 17$ & $381,627.70$ & 10.15 & 62.65 & 68.9 \\
\hline Total & $2,087,786.10$ & & & \\
\hline
\end{tabular}

Source: Economic Survey, Ministry of Finance, Nepal, F/Y 2011/12 to 2017/18

Ratio of indirect tax to GDP has shown overall increasing trend from $\mathrm{F} / \mathrm{Y} 2002 / 03$ at 3.91 percent up to $\mathrm{F} / \mathrm{Y}$ 2016/2017 at 10.15 percent with a decreasing trend in $\mathrm{F} / \mathrm{Y} 2005 / 06$ and 2010/11. On an average, indirect tax comprises of 6.29 percent of GDP. Ratio of indirect tax to government revenue has shown increasing as well as decreasing trend from $\mathrm{F} / \mathrm{Y}$ $2002 / 03$ at 55.03 percent up to $\mathrm{F} / \mathrm{Y} 2016 / 2017$ at 62.65 percent. It has shown decreasing trend on F/Y 2006/07 to $2008 / 09$ and again on $2010 / 11$ to $2012 / 13$. On an average, indirect tax comprises of 60.92 percent of government revenue. Ratio of indirect tax to tax revenue has shown increasing as well as decreasing trend from $\mathrm{F} / \mathrm{Y}$ 2002/03 at 73.39 percent up to $\mathrm{F} / \mathrm{Y} 2016 / 2017$ at 68.9 percent. It was highest on F/Y 2004/05 at 75.84 percent and lowest on $F / Y$ $2015 / 16$ at 68.35 percent. It has shown decreasing trend on F/Y 2006/07 to 2008/09, F/Y 2010/11 to $2012 / 13$ and $F / Y$ $2014 / 15$ to $2015 / 16$. On an average, indirect tax comprises of 72.74 percent of tax revenue.

\subsection{Structure of Resource Gap}

Total government expenditure consists of current expenditure, capital expenditure and principal payment expenditure. Total government income consists of revenue, foreign grants and difference amount. Resource gap is the measure of gap which occurs when the total government expenditure exceeds total government income. The figure shows the trend of resource gap due to total government expenditure and total government income over past fifteen $\mathrm{F} / \mathrm{Y}$.

Total government expenditure has been showing increasing trend from $\mathrm{F} / \mathrm{Y} 2002 / 03$ at 84,006.1 million to $\mathrm{F} / \mathrm{Y}$ $2016 / 17$ at 727,364 million which has increased by around 8.65 times over fifteen $\mathrm{F} / \mathrm{Y}$. On an average, total government expenditure has been $266,894.15$ million. Total government income has been showing increasing trend from F/Y 2002/03 at $67,568.9$ million to $\mathrm{F} / \mathrm{Y} 2016 / 17$ at 644,530 million which has increased by around 9.5 times over fifteen $\mathrm{F} / \mathrm{Y}$. On an average, total government income has been 253454.56 million. Resource gap has been showing increasing as well as decreasing trend. On F/Y 2002/03, it is 16,437.2 million and has decreased on F/Y 2003/04 to 15,828.2 million. From F/Y 2004/05, it has again increased up to $F / Y 2008 / 09$ at 49,804.7. Again, on F/Y 2009/10 it has drastically reduced to 10,569.48 million and increased on F/Y 2011/12 to 13,196.91 million and once again decreased on $\mathrm{F} / \mathrm{Y} 2012 / 13$ to 7053.92 million. There is no resource gap from $\mathrm{F} / \mathrm{Y} 2012 / 13$ to $2015 / 16$, instead there is resource surplus, which is a good sign to the economy of country. Again, on F/Y 2016/17, resource gap of 82,834 million is obtained which is highest gap over all fifteen $\mathrm{F} / \mathrm{Y}$. 


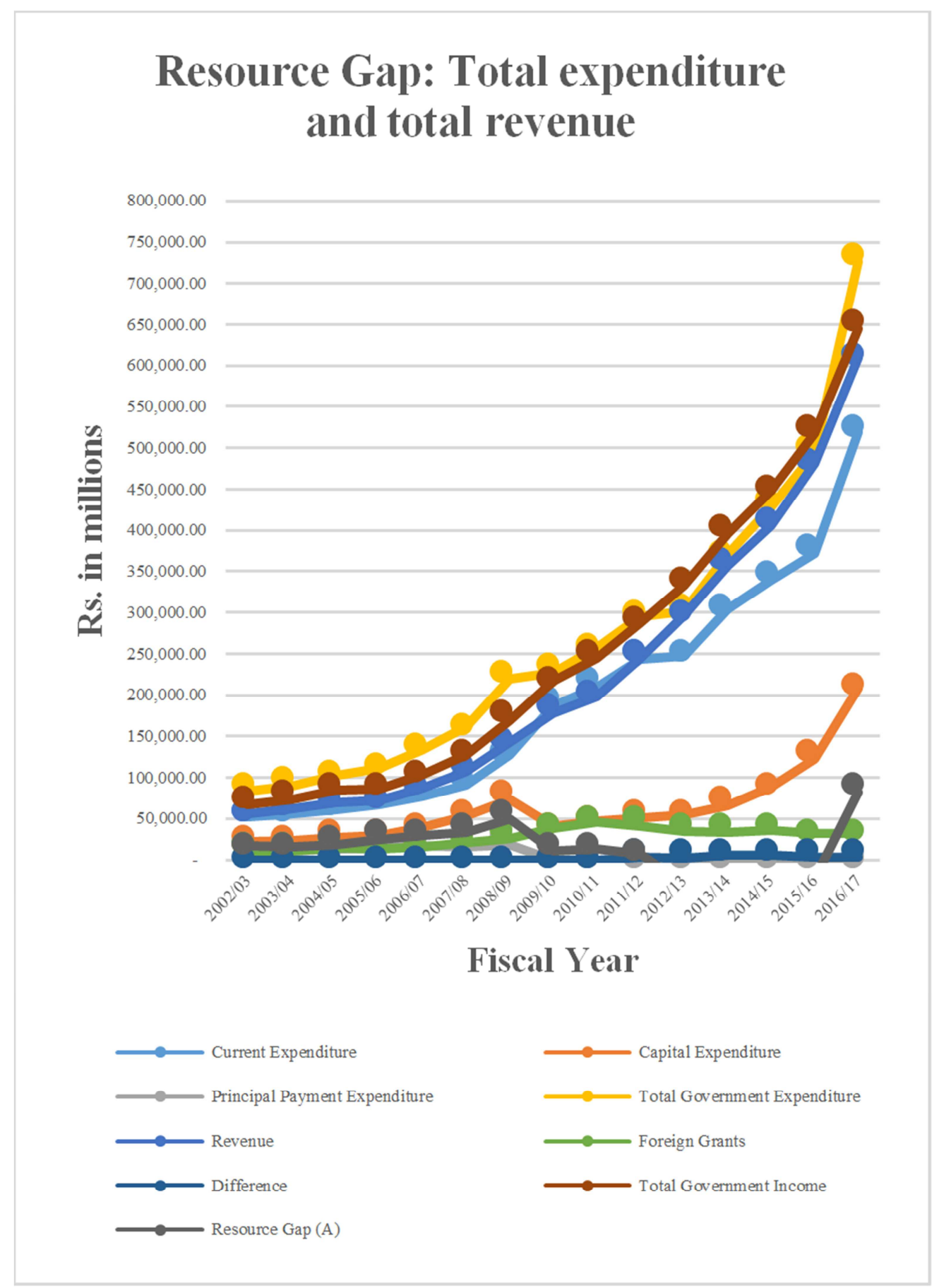

Source: Economic Survey, Ministry of Finance, Nepal, F/Y 2011/12 to 2017/18

Figure 1. Structure of Resource Gap for past fifteen Fiscal years.

\subsection{Co-relation Analysis}

Co-relation between GDP at basic price and nationwide tax revenue have been calculated. (Appendix 1) Let GDP at basic price and tax revenue be represented by variable $(\mathrm{X})$ and $(\mathrm{Y})$ respectively. Here, the co-relation coefficient between $(\mathrm{X})$ and $(\mathrm{Y})$ is $(\mathrm{r})=0.981$. This means correlation is strong and the variables are positively co-related. Thus, the correlation is significant at 0.01 level of significance. Similarly, also we have Co-relation between government revenue at basic price and nationwide tax revenue. (Appendix 2) Let government revenue and tax revenue be represented by variable $(\mathrm{X})$ and $(\mathrm{Y})$ respectively. Then corelation between $(\mathrm{X})$ and $(\mathrm{Y})$ is $(\mathrm{r})=1$. This means correlation is strong and the variables are positively corelated. Thus, the correlation is significant at 0.01 level of significance.

\subsection{Multiple Regression Analysis}

Multiple regression of government revenue with direct tax 
and indirect tax have been calculated. (Appendix 3) We have equation of multiple regression, $\mathrm{Y}=\mathrm{a}+\mathrm{b}_{1} \mathrm{X}_{1}+\mathrm{b}_{2} \mathrm{X}_{2}$. Where, $\mathrm{Y}=$ Government revenue, $\mathrm{a}=\mathrm{Y}$ intercept, $\mathrm{b}=$ Slope coefficient, $\mathrm{X}_{1}=$ Direct tax, $\mathrm{X}_{2}=$ Indirect tax. The correlation value of $\mathrm{R}$ is 1 . It means the combined correlation between direct tax and indirect tax with government revenue is 1 which implies that the independent variables are strongly and positively correlated with government revenue. Coefficient of determination $\mathrm{R}$ square is a statistical measure of closeness of data fitted in regression line. $\mathrm{R}$ square and adjusted $\mathrm{R}$ square is obtained 0.999. It implies the model explains 99.99 percent variability around its mean. In general, the higher the R-squared, the better the model fits the data. Putting the values of constant and coefficients in the regression equation $\mathrm{Y}=11479.57+1.244 \mathrm{~b}_{1}+1.032 \mathrm{~b}_{2}$. From the analysis of data of past fifteen years, the $\mathrm{Y}$ intercept ' $\mathrm{a}$ ' is 11479.57 which indicates that the value of government revenue becomes 11,479.57 million rupees when all two independent variables, direct tax and indirect tax are zero. When direct tax increases by one time, government revenue increases by 1.244 times. Similarly, when indirect tax increases by one time, government revenue increases by 1.032 times. The $t-$ value of direct tax and indirect tax are 4.855 and 8.865 respectively with p-value less than 0.05 at 5 percent level of significance. It shows that the overall independent variables are significantly related to dependent variable thus, the alternative hypothesis and accepted whereas, null hypothesis is rejected. The calculated F-value is 7271.364 at 0.000 significance which shows the calculated $F$ is greater than tabulated F. It shows that null hypothesis is rejected and alternative hypothesis is accepted at 5 percent level of significance.

\subsection{Time Series Analysis}

Time series analysis of tax revenue has been calculated. (Appendix 4) Tax revenue from F/Y 2002/03 to 2016/17 is taken as dependent variable (Y) and time from fiscal year $2002 / 03$ to $2016 / 17$ is taken as independent variable (X). Thus, the time series shows that nationwide tax revenue shall be $590,811.33$ million rupees in five years later in $F / Y$ $2021 / 25$ if the trend of past fifteen years continues in this way.

\section{Conclusion and Recommendations}

Over the past fifteen fiscal years, tax revenue has been primary source of government revenue. It has a distinct contribution to GDP, government revenue. It constituted of direct tax and indirect tax. In comparison to direct tax, indirect tax has higher contribution to tax revenue, government revenue and GDP. A fluctuating trend has been observed on the resource gap due difference in total government expenditure and total government income over past fifteen years. Also, there has been years when resource surplus was observed. At present, the country has been heavily relying on imports which would only enlarge the ambit of indirect tax which actually causes inflation and rise in resource gap. Scope of direct tax has not been broadened by the government. The statistical tools demonstrated that GDP and government revenue have been strongly related and dependent on the overall direct and indirect tax. Thus overall taxation has strong positive impact on government revenue. The scope and regulation for tax must be improved and strictly adhered. As indirect tax contributed higher proportion to government revenue, indirect tax levy and collection must be encouraged. Service tax is still not introduced in the country. For broadening the scope of indirect tax many countries had implemented service tax and now have implemented Goods and Service Tax for applying uniform indirect tax on all goods and services, but we are far behind in this regard. VAT is charged at flat thirteen percent but this is not a correct practice. It is recommended that, basic and essential goods required for daily consumption of general public must have lower percentage of VAT.

\section{Acknowledgements}

First of all, I would like to thank Tribhuvan University for giving me the chance to prepare the thesis for a partial fulfillment of the requirement for the Masters Degree of Business Studies program held under Tribhuvan University. After the long period of continuous survey and sincere efforts, this research has been conducted. On this occasion, I would like to thank all supportive people who directly or indirectly guided me to draft a dissertation in this issue. I also owe my deep gratitude to all the reputed authors whose books and journals have provided me the necessary guidance and invaluable materials for the enrichment of my research paper. In this regard, I also would like to remember all my colleagues, friends, the lectures and administrative staffs of Nepal Commerce Campus, my family members for their continuous support and helping me in this research work.

\section{Appendix}

\section{Appendix 1}

Table 5. Co-relation between GDP and tax revenue (Rs. in million).

\begin{tabular}{lll}
\hline F/Y & GDP at basic price & Tax revenue \\
\hline $2002 / 03$ & $767,582.00$ & $40,896.00$ \\
$2003 / 04$ & $837,682.00$ & $48,173.00$ \\
$2004 / 05$ & $914,088.00$ & $54,104.70$ \\
$2005 / 06$ & $1,013,977.00$ & $57,430.40$ \\
$2006 / 07$ & $1,126,300.00$ & $71,126.70$ \\
$2007 / 08$ & $1,264,601.00$ & $85,155.50$ \\
$2008 / 09$ & $1,508,850.00$ & $117,051.90$ \\
$2009 / 10$ & $1,772,694.00$ & $159,785.30$ \\
$2010 / 11$ & $2,052,228.00$ & $177,227.20$ \\
$2011 / 12$ & $2,298,248.00$ & $211,722.60$ \\
$2012 / 13$ & $2,525,886.00$ & $259,214.90$ \\
$2013 / 14$ & $2,876,673.00$ & $312,441.20$ \\
$2014 / 15$ & $3,099,248.00$ & $355,955.70$ \\
$2015 / 16$ & $3,243,996.00$ & $421,096.60$ \\
$2016 / 17$ & $3,759,190.00$ & $553,867.00$ \\
\hline
\end{tabular}

Source: Economic Survey, Ministry of Finance, Nepal, F/Y 2011/12 to 2017/18 


\begin{tabular}{llll}
\hline Correlations & GDP at basic price & Tax revenue \\
\hline \multirow{2}{*}{ GDP at } & Pearson correlation & 1 & $.981^{* *}$ \\
basic price & sig. (2-tailed) & & 0 \\
& $\mathrm{~N}$ & 15 & 15 \\
Tax & Pearson correlation & $.981^{* *}$ & 1 \\
revenue & sig. (2-tailed) & 0 & \\
& $\mathrm{~N}$ & 15 & 15 \\
\hline
\end{tabular}

**. Correlation is significant at the 0.01 level (2-tailed).

\section{Appendix 2}

Table 6. Co-relation between government revenue and tax revenue (Rs. in million).

\begin{tabular}{lll}
\hline F/Y & Government revenue & Tax revenue \\
\hline $2002 / 03$ & $54,538.90$ & $40,896.00$ \\
$2003 / 04$ & $62,331.00$ & $48,173.00$ \\
$2004 / 05$ & $70,122.70$ & $54,104.70$ \\
$2005 / 06$ & $72,281.90$ & $57,430.40$ \\
$2006 / 07$ & $87,712.10$ & $71,126.70$ \\
$2007 / 08$ & $107,622.50$ & $85,155.50$ \\
$2008 / 09$ & $143,474.50$ & $117,051.90$ \\
$2009 / 10$ & $177,991.70$ & $159,785.30$ \\
\hline
\end{tabular}

\section{Appendix 3}

\begin{tabular}{lll}
\hline F/Y & Government revenue & Tax revenue \\
\hline $2010 / 11$ & $198,375.90$ & $177,227.20$ \\
$2011 / 12$ & $244,374.00$ & $211,722.60$ \\
$2012 / 13$ & $296,021.10$ & $259,214.90$ \\
$2013 / 14$ & $356,620.70$ & $312,441.20$ \\
$2014 / 15$ & $405,866.40$ & $355,955.70$ \\
$2015 / 16$ & $481,961.60$ & $421,096.60$ \\
$2016 / 17$ & $609,180.00$ & $553,867.00$ \\
\hline
\end{tabular}

Source: Economic Survey, Ministry of Finance, Nepal, F/Y 2011/12 to 2017/18

\begin{tabular}{llll}
\hline Correlations & & Government revenue & Tax revenue \\
\hline \multirow{2}{*}{ Government } & Pearson correlation & 1 & $1.000^{* *}$ \\
revenue & sig. (2-tailed) & & 0 \\
& $\mathrm{~N}$ & 15 & 15 \\
\multirow{5}{*}{ Tax revenue } & Pearson correlation & $1.000^{* *}$ & 1 \\
& sig. (2-tailed) & 0 & \\
& $\mathrm{~N}$ & 15 & 15 \\
\hline
\end{tabular}

**. Correlation is significant at the 0.01 level (2-tailed).

Table 7. Multiple regression among government revenue, direct tax and indirect tax (Rs. in million).

\begin{tabular}{llll}
\hline F/Y & Government revenue & Direct tax & Indirect tax \\
\hline $2002 / 03$ & $54,538.90$ & $10,881.90$ & $30,014.10$ \\
$2003 / 04$ & $62,331.00$ & $11,912.60$ & $36,260.40$ \\
$2004 / 05$ & $70,122.70$ & $13,071.80$ & $41,032.90$ \\
$2005 / 06$ & $72,281.90$ & $13,968.10$ & $43,462.30$ \\
$2006 / 07$ & $87,712.10$ & $18,980.30$ & $52,146.40$ \\
$2007 / 08$ & $107,622.50$ & $23,087.70$ & $62,067.80$ \\
$2008 / 09$ & $143,474.50$ & $34,319.70$ & $82,731.20$ \\
$2009 / 10$ & $177,991.70$ & $40,396.00$ & $119,389.30$ \\
$2010 / 11$ & $198,375.90$ & $46,720.30$ & $130,506.90$ \\
$2011 / 12$ & $244,374.00$ & $57,770.20$ & $153,951.60$ \\
$2012 / 13$ & $296,021.10$ & $73,012.60$ & $186,202.30$ \\
$2013 / 14$ & $356,620.70$ & $86,742.30$ & $225,698.90$ \\
$2014 / 15$ & $405,866.40$ & $101,089.20$ & $254,866.50$ \\
$2015 / 16$ & $481,961.60$ & $133,268.80$ & $287,827.80$ \\
$2016 / 17$ & $609,180.00$ & $172,238.70$ & $381,627.70$ \\
\hline
\end{tabular}

Source: Economic Survey, Ministry of Finance, Nepal, F/Y 2011/12 to 2017/18

\begin{tabular}{llll}
\hline Variables entered/removed $^{\mathbf{a}}$ & & & \\
\hline Model & Variables Entered & Variables Removed & \\
\hline 1 & Indirect Tax, Direct Tax & Method & \\
\hline
\end{tabular}

a. Dependent Variable: Government Revenue

b. All requested variables entered.

\begin{tabular}{llll}
\hline Model Summary & & \\
\hline Model & R & R Square & Adjusted R Square \\
\hline 1 & $1.000^{\mathrm{a}}$ & 0.999 & 0.999 \\
\hline
\end{tabular}

a. Predictors: (Constant), Indirect Tax, Direct Tax

\begin{tabular}{|c|c|c|c|c|c|c|}
\hline \multicolumn{7}{|c|}{ ANOVA $^{a}$} \\
\hline & & Sum of Squares & Df & Mean Square & $\mathbf{F}$ & Sig. \\
\hline \multirow{3}{*}{1} & Regression & $4.13754 \mathrm{E}+11$ & 2 & $2.06877 \mathrm{E}+11$ & 7271.364 & $.000^{\mathrm{b}}$ \\
\hline & Residual & 341410860.9 & 12 & 28450905.08 & & \\
\hline & Total & $4.14095 \mathrm{E}+11$ & 14 & & & \\
\hline
\end{tabular}

a. Dependent Variable: Government Revenue

b. Predictors: (Constant), Indirect Tax, Direct Tax 


\begin{tabular}{|c|c|c|c|c|c|c|}
\hline \multicolumn{7}{|c|}{ Coefficients $^{\mathrm{a}}$} \\
\hline \multirow{2}{*}{\multicolumn{2}{|c|}{ Model }} & \multicolumn{2}{|c|}{ Unstandardized Coefficients } & \multirow{2}{*}{$\begin{array}{l}\text { Standardized Coefficients } \\
\text { Beta }\end{array}$} & \multirow[b]{2}{*}{$\mathbf{t}$} & \multirow[b]{2}{*}{ Sig. } \\
\hline & & B & Std. Error & & & \\
\hline \multirow{3}{*}{1} & (Constant) & 11479.57 & 2918.011 & & 3.934 & 0.002 \\
\hline & Direct Tax & 1.244 & 0.256 & 0.354 & 4.855 & 0 \\
\hline & Indirect Tax & 1.032 & 0.116 & 0.647 & 8.865 & 0 \\
\hline
\end{tabular}

a. Dependent Variable: Government Revenue

\section{Appendix 4}

Table 8. Time series analysis of tax revenue (Rs. in million).

\begin{tabular}{ll}
\hline F/Y & Tax revenue \\
\hline $2002 / 03$ & $40,896.00$ \\
$2003 / 04$ & $48,173.00$ \\
$2004 / 05$ & $54,104.70$ \\
$2005 / 06$ & $57,430.40$ \\
$2006 / 07$ & $71,126.70$ \\
$2007 / 08$ & $85,155.50$ \\
$2008 / 09$ & $117,051.90$ \\
$2009 / 10$ & $159,785.30$ \\
$2010 / 11$ & $177,227.20$ \\
$2011 / 12$ & $211,722.60$ \\
$2012 / 13$ & $259,214.90$ \\
$2013 / 14$ & $312,441.20$ \\
$2014 / 15$ & $355,955.70$ \\
$2015 / 16$ & $421,096.60$ \\
$2016 / 17$ & $553,867.00$ \\
\hline
\end{tabular}

Source: Economic Survey, Ministry of Finance, Nepal, F/Y 2011/12 to 2017/18

\section{Time Series Analysis of Tax Revenue}

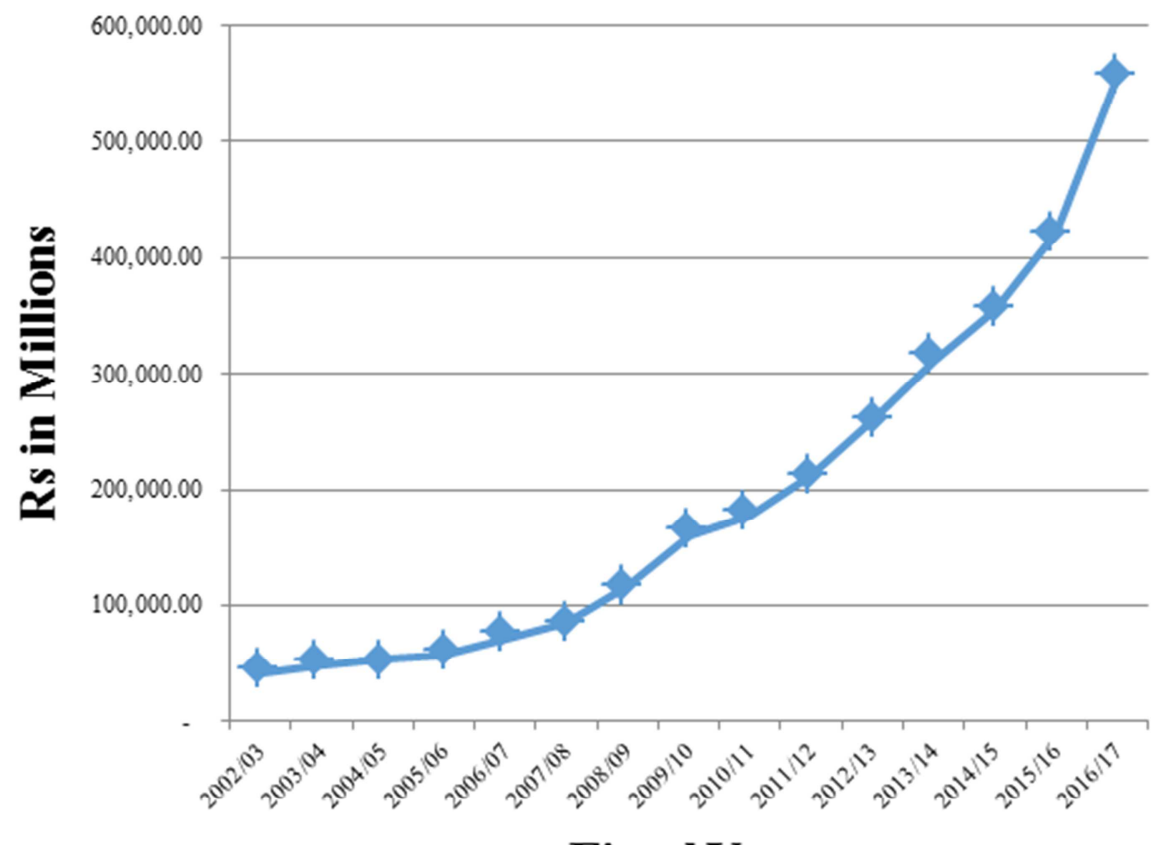

Fiscal Year

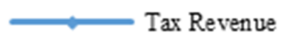

Figure 2. Time series analysis of tax revenue. 
Table 9. Calculation for least square method.

\begin{tabular}{|c|c|c|c|c|}
\hline Fiscal year & Deviation taken from the year of origin $(X)$ & Tax revenue $(I)$ & $X^{2}$ & $X Y$ \\
\hline $2002 / 03$ & -7 & $40,896.00$ & 49 & $-286,272.00$ \\
\hline 2003/04 & -6 & $48,173.00$ & 36 & $-289,038.00$ \\
\hline $2004 / 05$ & -5 & $54,104.70$ & 25 & $-270,523.50$ \\
\hline $2005 / 06$ & -4 & $57,430.40$ & 16 & $-229,721.60$ \\
\hline 2006/07 & -3 & $71,126.70$ & 9 & $-213,380.10$ \\
\hline $2007 / 08$ & -2 & $85,155.50$ & 4 & $-170,311.00$ \\
\hline 2008/09 & -1 & $117,051.90$ & 1 & $-117,051.90$ \\
\hline $2009 / 10$ & 0 & $159,785.30$ & 0 & - \\
\hline 2010/11 & 1 & $177,227.20$ & 1 & $177,227.20$ \\
\hline 2011/12 & 2 & $211,722.60$ & 4 & $423,445.20$ \\
\hline $2012 / 13$ & 3 & $259,214.90$ & 9 & $777,644.70$ \\
\hline $2013 / 14$ & 4 & $312,441.20$ & 16 & $1,249,764.80$ \\
\hline $2014 / 15$ & 5 & $355,955.70$ & 25 & $1,779,778.50$ \\
\hline $2015 / 16$ & 6 & $421,096.60$ & 36 & $2,526,579.60$ \\
\hline $2016 / 17$ & 7 & $553,867.00$ & 49 & $3,877,069.00$ \\
\hline Total & $\sum X=0$ & $\sum Y=2,925,248.70$ & $\sum X^{2}=280$ & $\sum X Y=9,235,210.90$ \\
\hline
\end{tabular}

The equation of straight line trend is:

$$
\mathrm{Y}=\mathrm{a}+\mathrm{bX}
$$

Where, $\mathrm{Y}=$ Dependent variable i.e., tax revenue,

$\mathrm{X}=$ Independent variable i.e., time

Using Least Square Method the value of variable 'a' and variable 'b' can be obtained through

$$
\begin{aligned}
\sum \mathrm{Y} & =\mathrm{Na}+\sum \mathrm{X} \\
\sum \mathrm{XY} & =\mathrm{a} \sum \mathrm{X}+\mathrm{b} \sum \mathrm{X}^{2}
\end{aligned}
$$

Let year of origin is F/Y 2009/10. From Eqn. (4) and according to Table 9,

$$
\begin{gathered}
\sum \mathrm{Y}=\mathrm{Na}+\sum \mathrm{X} \\
\mathrm{a}=\left(\sum \mathrm{Y}\right) / \mathrm{N}\left[\text { as } \sum \mathrm{X}=0\right] \\
\mathrm{a}=2925248.7 / 15=195016.58
\end{gathered}
$$

From Eqn. (5),

$$
\begin{gathered}
\sum \mathrm{XY}=\mathrm{a} \sum \mathrm{X}+\mathrm{b} \sum \mathrm{X}^{2} \\
\sum \mathrm{XY}=\mathrm{b} \sum \mathrm{X}^{2}\left[\text { as } \sum \mathrm{X}=0\right] \\
\mathrm{b}=\left(\sum \mathrm{XY}\right) /\left(\sum \mathrm{X}^{2}\right) \\
\mathrm{b}=9235210.9 / 280=32982.9
\end{gathered}
$$

The equation of straight line trend is for $\mathrm{F} / \mathrm{Y}$ 2021/22, 5 years from $\mathrm{F} / \mathrm{Y} 2016 / 17$, where $\mathrm{X}=12$ is,

$$
\begin{gathered}
\mathrm{Y}=\mathrm{a}+\mathrm{bX} \\
\mathrm{Y}=195016.58+32982.9 \times 12 \\
\mathrm{Y}=590811.33
\end{gathered}
$$

\section{References}

[1] M. Feldstein, "The Effects of Tax-Based Saving Incentives on Government Revenue and National Saving”, Quarterly Jounal of Economics, May 1995, pp. 475-494.
[2] Nepal Rastra Bank, "Trend in Nepal's import duties: Implications with future trade liberalization", Economic review: Special studies division, research department, 2002, pp. 152-176.

[3] A. S. Gupta, "Determinats of Tax Revenue Efforts in Developing Countries," IMF Working Paper, July 2007, pp. 1-39.

[4] J. B. K. C., "Tax Laws and Tax Planning”, Khanal Books \& Stationery, 2006.

[5] R. Taha and N. Loganathan, "Causality between Tax Revenue and Government Spending in Malaysia", The International Journal of Business and Finance Research, January 2008, pp. 63-73.

[6] J. Agrawal, "Income Tax: Theory and Practice", Ayam Publication, 2009.

[7] U. S. Prasad, "Nepal's excise systems and the legal frameworks: agendas for reform", World customs journal, Vol. 9, No. 2, October 2015, pp. 53-70.

[8] A. Yadav, M. Ali, M. Aris and S. Tuladhar, "Contribution of income tax and effects on revenue generation of Nepal", International Journal of Scientific and Engineering Research, Vol. 6, Issue 1, January 2015, pp. 1200-1203.

[9] D. Rossinglo, "Taxes, Expenditures, Poverty and Income Distribution in Argentina", Commitment to Equity, Working Paper 45, May 2016.

[10] O. Morrissey, C. V. Haldenwang, A. V. Schiller, M. Invanyna, I. Bordon, "Tax Revenue Performance and Vulnerability in Developing Countries", The Journal of Developing Studies, Vol. 52, No. 12, May 2016, pp. 1689-1703.

[11] M. T. Ajayi, I. Onuigbo, S. I. Shuaib, Z. S. Zafirah, "An evaluation of the relationship between variations in provision of infrastructural and payment of property tax in Ibadan northeast local government, Nigeria", Journal of Technology Management and Business, Vol. 03, No. 02, 2016.

[12] G. Mascagni, "A Fiscal History of Ethiopia: Taxation and Aid Dependence 1960-2010", International Centre for Tax and Development, Working Paper 49, March 2016.

[13] K. D. Dhakal, I. P. Bhattarai, G. P. Koirala and R. Bhattarai, "Tax Laws \& Tax Planning in Nepal", Asmita Books \& Distributors, 2017. 
[14] Z. Ghodsi, A. Webster, "UK Taxes and Tax Revenues: Composition and Trends", Intech Open 74380, Vol. 10, April 2018, pp. 83-96.

[15] V. A. Mahler, "Indirect taxes and government inequality reduction: A cross-national analysis of the developed world", Journal of Income Distribution, July 2018, pp. 1-26.

[16] D. N. Gujrati, D. C Porter and S Gunasekar, "Basic Econometrics", McGraw Hill Education (India), 2015. 